\author{
Jerzy Sierociuk \\ Adam Mickiewicz University in Poznań \\ Institute of Polish Philology \\ ORCID: 0000-0001-9069-6117; e-mail: jasier@amu.edu.pl
}

\title{
Features defining dialects spoken in language of villagers
}

\begin{abstract}
The article focuses on the suitability of collections of texts for listing dialect characteristics. Attention has also been paid to the occurrence of some dialectal features in Z. Sobierajski's Teksty z zachodniej Wielkopolski; 210 pages of his book contain 62,711 dialectal word forms. The material from the corpus has been confronted with M. Gruchmanowa's Gwary zachodniej Wielkopolski (Poznań 1970) and the Atlas języka i kultury ludowej Wielkopolski (Wrocław...- Poznań 1979-2005). The corpus either lacks an entire group of forms regarded typical of the region's dialects or the occurrences are very rare. Therefore, despite the ample material, in many instances an attempt at linguistic characteristics of specific dialects is futile.
\end{abstract}

Keywords: dialect, language spoken in rural areas, dialectal system, text rendition.

\begin{abstract}
Abstrakt: Cechy definicyjne gwar w języku mieszkańców wsi. Artykuł koncentruje się na problemie przydatności zbiorów tekstów do zestawiania charakterystyki gwar. Zwrócono tu uwagę na występowanie niektórych cech dialektalnych w książkowym wydaniu Tekstów z zachodniej Wielkopolski Z. Sobierajskiego. $\mathrm{Na} 210$ stronach druku odnotowanych jest 62711 słowoform gwarowych. Materiał z tak zestawionego korpusu skonfrontowany został z M. Gruchmanowej Gwarami zachodniej Wielkopolski (Poznań 1970) i Atlasem języka i kultury ludowej Wielkopolski (Wrocław ...-Poznań 1979-2005). Cały szereg form, uznawanych za typowe dla gwar tego regionu, w badanym korpusie nie występuje, lub ma poświadczenia jednokrotne. Mimo więc tak obfitego materiału w wielu wypadkach nie jest możliwe podjęcie prób naszkicowania charakterystyki językowej konkretnych gwar.
\end{abstract}

Wyrazy kluczowe: gwara, język mieszkańców wsi, system gwarowy, realizacja tekstowa.

In the dialectological tradition or, more broadly, in the linguistic tradition, dialectal texts are regarded a very important source used to characterise a specific dialect. To a large extent, the material available in the publications represents the basis of monographs and it is also highly valued in lexicography. Notably, until recently collections of dialectal texts provided in fact the only opportunity to study the dialectal diversity in any language. However, for obvious reasons hand-written utterances of inhabitants of rural areas did not represent relevant research material. In many instances, their suitability depended on the documentalist's professional preparation. It was not until phonographic registration that the volume as well as the diversity of the accounts could be increased. Listening to the recordings numerous times posed an opportunity 
for an in-depth analysis. Contact with a substitute of a live language has enjoyed growing popularity in academic teaching.

Kazimierz Nitsch's Wybór polskich tekstów gwarowych (Nitsch 1929) has played a very important role in Polish linguistic studies. A collection of dialectal texts, published in the Interwar period with a large group of student of Polish philology and other specialisations in mind, was a major source of knowledge that enabled to present the specific dialectal complexes. Registered live language spoken by inhabitants of rural areas was not available before the phonographic archive at the Poznan University was made partly available (more in Sierociuk 2009).

The article's material basis is represented by a fragment of a lexicographic corpus of the Dialectology Laboratory of the Poznan University developed for the purpose of the future dictionary of Wielkopolska's dialects. The utterances were registered in the early 1950s by Zenon Sobierajski; some of them are available in Teksty gwarowe $z$ zachodniej Wielkopolski (Sobierajski 1985). A book of 210 pages presents utterances of inhabitants of 11 villages from a compact dialectal area. For the purpose of the corpus, the material was rewritten in a simplified form to replace the original phonetic transcription and submitted to digital processing. The corpus includes only dialectal word forms from the analysed texts. The collection contains 62,711 units.

In the computer database, each form ("flashcard") has a few pieces of information; with view of further analysis, of importance may be the initials identifying the informant, his/her year of birth, place of residence and the day of the recording. Once the material has been sorted, a specification of the usage of all the forms has been drafted; it provides insight into the phenomenon's territorial and idiolectal prevalence. With a rich and diverse material at hand, we can identify various chronological (generational) layers of the local linguistic features. A case of making use of this type of information is the type jeszczyk 'jeszcze' (still) which appeared quite frequently, namely 22 times. The form was confirmed in four locations. For these considerations, on top of the geographic information of importance is the idiolectal distribution: Drawsko (informant born in 1866) - twice; Nowa Wieś Zbąska (informant born in 1866) once; Stare Kramsko (informant born in 1874) - twice; Kębłowo (informant born in 1874) - 17 times.

In each location, this example was registered in one informant's speech; bearing in mind the fact that there were several interlocutors taking part in these conversations (three males in Kębłowo), the above findings are meaningful, especially with reference to the material from Kębłowo. The situation unambiguously shows that dialectal documentation may reflect phenomena typical of specific idiolects.

Another reason why the jeszczyk type deserves is that the lack of confirmation thereof in contemporary recordings clearly indicates that the phenomenon is obsolete. It also shows that, in the course of an analysis of archived materials, a researcher may come across idiolectal confirmations, sometimes even single. Examination of archived materials leads to a question if this type of examples may be at the heart of the characteristics of a specific dialect.

In the database, the zernik 'rzeźnik' (butcher) type has characteristic confirmations, 6 of them in just one location (Drawsko) and from one informant at that. The subsequent question seems obvious: is it a dialectal or idiolectal feature? 
Before I proceed with the major topic, let me devote some attention to the possibility of indicating the phenomena in the article's title.

The dialectal texts, published by Z. Sobierajski, were recorded in the 1950s following the rules formulated by Jan Otrębski (Otrębski 1953), listed for the purpose of a dialectal phonographic archive. The assumed thematic diversity of the recordings is reflected in the analysed specification of west Wielkopolska texts. The founders of the Poznań archive assumed that these were texts representative of the documented dialects. When working on the selection, Z. Sobierajski assumed that "in the future, the texts (...) may provide a valuable material basis for further research split into two areas, namely dialectology and ethnology". (Sobierajski 1985, 5).

Therefore, the selection of a group of texts for scrutiny resulted from, among other things, willingness to test their suitability "for further research". To be more specific, two premises prevailed: the lexical representation of Wielkopolska dialects ("Only texts lexically explored for the "Słownik gwar polskich", compiled under the supervision of M. Karaś were regarded" (Sobierajski 1985, 5)) and the heavily stressed conviction that the lexical material was so abundant that in the future, it might provide the basis for a Wielkopolska dictionary. The author of these large selections of dialectal texts wrote:

there is ample material for further work on Wielkopolska folk culture, material and social alike (...).

Needless to say, a Polish philologist will find lots of materials for further research into the regional Polish language spoken in Wielkopolska, within the resources of all the sections of the language system. The multitude of the lexical material can be used in the course of editing the "Słownik gwarowy Wielkopolski (na tle kultury ludowej)" (Sobierajski 1995, 5160 x 2356).

Not surprisingly, the above led to a conviction that the texts were representative, also about other levels of organisation of the system of dialects ("A dialectologist will find lots of material from all sections of the language system" (Sobierajski 1985, 5).

Therefore, are thematically diverse texts containing 62,711 word forms a sufficient corpus to make an attempt at constructing a relatively complete profile of the dialects in question?

There are several works in Polish dialectology that allow to confront the corpus material with monographs. The dialectal picture of west Wielkopolska is presented mainly in two works, namely in the Atlas jezzyka $i$ kultury ludowej Wielkopolski (AJKLW 1979-2005) and Gwary zachodniej Wielkopolski by Monika Gruchmanowa (Gruchmanowa 1970). However, when juxtaposing these texts with material compiled by $\mathrm{Z}$. Sobierajski, one should be aware that they were used by both M. Gruchmanowa and the team editing the atlas. Nevertheless, the question about the occurrence of features defining dialects in these rather lengthy texts is absolutely intriguing.

The Atlas... and M. Gruchmanowa's monograph pose an opportunity to compare the analysed corpus and the findings presented by field researchers; the latter work is a confrontation of the confirmations from Z. Sobierajski's recordings with a database including material from explorations carried out for the purpose of a dictionary of Wielkopolska dialects. 
By submitting the comments below I do not assume that an analysis of the entire dialectal system is possible; my intention is only to decide if this type of corpus is representative enough for subsequent attempts at a monograph of the specific dialects. The issue gains in importance when, for example, a dictionary of dialects is compiled. To what extent can a researcher be satisfied with longer utterances of inhabitants of rural areas and to what extent do we have to resort to the semi-questionnaire method to obtain lexicographic material?

Let me proceed with more concrete examples.

Phonetic phenomena:

The texts recorded by Z. Sobierajski document the prevalence of the typical features defining Wielkopolska dialects: lack of mazuration and voicing interword phonetics; equally common are diphthongs, typical of the region. While indication of these primary defining features is not at all problematic, peculiar features were registered much less frequently.

Forms like graje, grajesz, znaje, znajesz (Nowak 1982: 33) are regarded characteristic of a large part of dialects of Wielkopolska as well as Kashubia, Krajna, north and south Wielkopolska and a part of Silesia. The corpus of my interest includes only znaje, confirmed once in Dąbrówka Wlkp., Podmokle Wielkie and Jażyniec. There are no other dependent forms; the corpus does not contain confirmations of the graje type.

Assuming that a monograph includes forms deemed typical of a region, let me take a look at their representation in the analysed corpus.

According to the monograph (Gruchmanowa 1970, map 14), 'skrzydło' is used in the area's dialects in the following forms: krzydło, skrzydło and śkrzydło; two of these forms occur in texts while krzydło has two confirmations; skrzydło has been written down three times; in Z. Sobierajski's texts, the form ckrzydto was recorded, unknown to M. Gruchmanowa;

'pszczoła' (bee) - no form has been recorded in the texts; (Gruchmanowa 1970, map 9) presents two forms: pszczoła and pczoła;

'szkło' (glass) - out of the forms ćkło, czkło and szkło (Gruchmanowa 1970, map 8), only the first type is confirmed: ćkło - 3 times, ćklónka - 3 times; types czkło and szkło were not recorded;

'rumianek' (camomile) - according to the monograph (Gruchmanowa 1970, map 92), two forms occur in the area in question: rumianek and rymianek; Z. Sobierajski's texts do not confirm it;

byś 'być' (to be) regarded typical of this area, confirms this attribute in the texts; even today, older respondents use this form;

roście 'rośnie' (grows) - quoted 3 times by informants from Dąbrówka Wlkp. and 3 times in Podmokle Wielkie;

bojewica (a place in a barn to park a cart) occurred in various locations in Z. Sobierajski's register;

kóniewi (to a horse) - a sporadic form in the corpus - confirmed once.

The possibility of obtaining word-formation structures is much more complex. In the specific conditions of research into word-formation in linguistics in the mid- $20^{\text {th }}$ 
century, interest in these forms was slight. Nevertheless, one could expect occurrence of some lexical units representing specific ford-formation types. The west Wielkopolska corpus does not contain many names of locations; confirmations like bielnik 'a place where yarn is whitewashed' are rare or sporadic (once); kurnik (3 times); formations with the -isko suffix are also rare: siedlisko (fish habitat), szczernisko (stubble field), topawiska. In the analysed corpus, only three augmentatives are present: wiórzysko - 3 times, ptaszysko, weselisko. In Z. Sobierajski's texts, names of professions are rare; there is a rzeźnik type, a strażnik (once), a stelmach and a sukienik // sukiennik (3 times); the form rzeźnik (a butcher) was uttered by one informant as zernik. There are no representatives of the types kołodziej, kominiarz, powroźnik or pracownik, confirmed in other materials from this area.

While the texts contain references to harvest with mentions of various parts of the scythe, the lack of a name for "one who scythes" (kosiarz) is surprising; the dialects of west Wielkopolska include the words kośnik $k^{1}$ and kosiarz (AJKLW 1979-2005, map 331). According to the local standard, the texts also lack the kosic form; traditional west Wielkopolska dialects use the verb siec whose position, in the light of the texts, is also irrefutable. On the basis of an analysis of the relations in question, nothing can be said about words like 'a woman following a reaper' - not a single occurrence of the odbieraczka or ubieraczka type was registered.

The words dużki 'duży' (large), dużyko 'dużo' (lots of) are equally frequent in various locations; they are also confirmed in contemporary materials.

The prevailing diminutive formant -yszek is regarded typical of Wielkopolska dialects; in the AJKLW 1979-2005, they forms colnyszek (m. 535), garnyszek (m. 59), grzebyszek (m. 333), kawatyszek (m. 25), mlastyszek (m. 56), rzymyszek (m. 471), stupyszek (m. 368), kundyszek (m. 25), spodyszek (m. 70), stotyszek (m. 39), toporyszek (m. 281), więcioryszek (m. 738), woryszek (m. 40) are confirmed in various locations and with varying intensity (map numbers in brackets). One could therefore expect at least a few recordings in the corpus material; however, the type rzymyszek occurs only once. In this situation, this type is hardly representative, especially that other materials from this area provide also chłopyszek, grzebyszek, kamyszek, kwiatyszek, snopyszek and wionyszek (on top of some forms registered in the atlas).

The documentation compiled by Z. Sobierajski poses hardly any opportunities to indicate the prevailing type; it is not possible to identify the relations between the types wianyszek and wianuszek because neither is confirmed; there is only the general Polish type wianek.

There is no reason to analyse the relations between the diminutive formants $-i k$ and -ek; the former is regarded characteristic of Wielkopolska dialects. The corpus lacks the wózik and wózek types; płocik and płotek are equally non-existent. There is not a single example of the kłosik, kłosek, kłoseczek series.

Due to the lack of textual representation of a specific type of vocabulary, it is impossible to make attempts at describing other word-formation relations. In the analysed corpus registered in the course of field exploration, there are no examples of the type

\footnotetext{
${ }^{1}$ I have disregarded a single confirmation of the word kośnik which was uttered in a reply to the explorer's question in which the word was mentioned.
} 
tanecznik 'one who dances well', brudas 'one who is dirty', brukarz 'one who lays cobbles', chapacz 'one who works hard, toils'; chlewnia as an alternation of chlew, chrześniak, chrześniaczka.

The persistence of forms gorzyć się, gorszyć się, gniewać się, indicated in the Atlas ... (AJKLW 1979-2005, map 601: Gniewać się and the synonyms) has not been confirmed, the type równik, równiak, rów(n)ieśnik, rówieśnik is non-existent (AJKLW 1979-2005, map 594: names of humans of the same age).

Let's also take a close look at the textual representation of the indicators of a feature's intensity, e.g.:

-utki: cieniutki (once), drobniutko (once), głaciutko (once), króciutkie (once), malut$k i$ (5 times), samiutki (once), świżutki (once); the forms czyściutki, czyściutko, mięciut$k i$ were not registered;

-uchn-: cieniuchno (once), żótciuchne (twice);

-eńki: drobniuteńkie (once);

-itki: malitki (once).

The above examples clearly indicate that it is impossible to instigate respective research based on this otherwise bulky material corpus.

In order to supplement these observations, let me refer to a comment on the name regarded typical of the Western sections of the analysed dialects, also by contemporary respondents: bulwa 'ziemniak' (potato). Its dispersion is presented in the AJKLW 1979-2005 - map 353. The picture emerging from Z. Sobierajski's texts is very telling: bulwa - once, pyra // pyrka - 104 times, kartofel - 6 times. Therefore, the picture is absolutely clear: the words pyra // pyrka are widespread; bulwa, regarded a representative form, is practically non-existent in the analysed texts.

One more example not related to vocabulary: the type po nogach "on foot", which occurs in various dialects of Wielkopolska, is represented only once, by the type po kolanach 'on bent knees'.

As I have indicated above, each form is accompanied by information of importance from the point of view of a sociolinguistic analysis. Bearing in mind only the generation factor (and the generation affinity is indicated by intervals of 25 years in the informants' dates of births) (Sierociuk 2003), we can indicate the chronological stratification of the language spoken by the inhabitants of the villages under scrutiny. Obviously, in many instances the texts registered in the 1950 s are the only confirmation of a specific form's persistence. A case in point is the type jeszczyk, absent from contemporary material. On the other hand, we need to bear in mind that absence of a specific form, especially when it concerns systemic phenomena, does not mean that the form does not exist in the structure of a specific dialect. In many cases, it only means that the form of interest did not appear in the analysed texts. A researcher needs to be aware of the systemic limitations which occur also in the general language (Skubalanka 1977). This should result in accepting the fact that following an analysis of even very large corpuses, it is not possible to indicate the ranges of specific phenomena. This article contains many examples of singular confirmations of phenomena of importance to the general characteristics of dialects in west Wielkopolska. If we want to obtain information of geographic nature, we need to be open to different methodological solutions and resort to questionnaire surveys. 
Sometimes, these corpuses' limited usefulness for lexicographic purposes is undeniable; lack of many important words related to harvest in materials collected by Z. Sobierajski (despite conversations on the subject) indicates a need for very specific field explorations. The most effective method is obtaining a respondent's longer, guided utterance (stimulated by a "questionnaire").

Finally, let me add one more observation: the texts compiled by Z. Sobierajski surprise with an attempt of subordinating a dialectal utterance to the rules of the literary Polish language. To this end, delimitation typical of the written language was employed where the text is divided into syntactic units. Sentences start with capital letters and end with a stop. There are also commas. This approach to a recorded material is clear evidence of the researcher's (the transcribing party's) interference. Some important features of dialectal syntax have therefore been removed.

Z. Sobierajski admitted that "before the recording, the utterance had to be prepared together with the informant to ensure that there were no longer pauses in the stories when the record was in the course of grooving" (Sobierajski 1985, 6). Therefore, the ultimate "product" was slightly processed at the beginning2; some phenomena are blurred - it is practically impossible to analyse the so-called small syntax. As the interlocutor was prepared for the recording, the chances of natural utterances were compromised. This "concern" was reflected in a lack of the element "nie" (no) in the registered conversations, very characteristic of the language spoken in Wielkopolska, used as a particle rather than negation.

In this context, let me compare three fragments from Dąbrówka Wlkp.:

\begin{abstract}
A co to jest ,biczyk"?
Biczyk to jez jak sie kóńczy pútno robić ... już ino ... i potym tag jeszczy ze ... trzý, śtyry razy sie tym czolnkiym przebije, żeby to sie nie wysypało $z$ te ... z tych chótwów $i$ z tych ... $z$ te plochy.
\end{abstract}

\title{
A co oznacza „lamanie Inu"?
}

A nó to gó trzymy, tag gó ... to my trzymy tó $o^{m}$ cierlicó $^{m}$, to ... to jesta lamanie. My mówimy

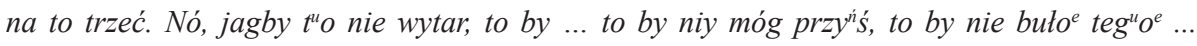
nó jak to sie mówi ... tego włosa by nie buto. Bo to by byta stóma, nie?

[Dąbrówka Wlkp., Świebodzin county; informant born in 1899; recorded in 1951 - Sobierajski 1985,91$]$.

Z. Sobierajski's selection of texts from Dąbrówka Wlkp. encompasses more than 18 printed pages (pp. 86-104); the lexical unit of interest to us did not appear even once. This is surprising because in recordings from that time (of informants representing different generations) the word nie was registered quite frequently. It is an element clearly indicating its function; in the text, it is indicated by a short pause on either side.

\footnotetext{
2 Similarly, there are no elements characteristic of spoken texts from the early, hand-written dialectological documentation; while dictating the text to the explorer, the informant tried to speak "nicely" i.e. without unnecessary ornaments or repetitions; see also (Nitsch 1929).
} 


\section{Co to jest baźka?}

A: baźka to sie kojarzy z czymś takim podtużnym ... o formie stożkowatej na końcu ... $i$ czymśs wiszon ${ }^{n}$ ym ... dyndajon cym sie ... jak ... zatóżmy ... w zygarach tych ... tych ścinnych ... na końcu tańcuszków takie ... takie so ${ }^{m}$... odważniki metalowe ... i to też mówili na to baźka ... bynajmniej $u$ naz $w$ domu ... nie ... i to to $^{m}$ baźkom pociongateś ... i naciongatyś spry ${ }^{n} \dot{z} y n e$... nie ...

B: roz tyn ... roz tyn ...

A: jedna była baźka do bicia ... a jedna była do odmirzania czasu ... dwie baźki ... a sosna szyszka ... a baźka to jez za krótkie ... chyba że by dzie jakiś kwiatek ... maty be dzie ... to ... ale be ${ }^{n} d z i e$ taki $w$ formie cylindrycznyj ... nie ... bo szyszka jest $w$ formie stożkowatyj ... i taka krótsza ... nie ... no a baźka sie z czymś kojarzy ...

[Dąbrówka Wlkp. Świebodzin county; informant A born in 1959, informant B born in 1923; recorded in 2007].

$$
* * *
$$

\section{A mlyńce i plince to było to samo?}

no ... zależy jak kto pozywat ...

I jak to się robilo?

te plynce (!) ... zimniaki sie tarlo ... no teroz so ${ }^{m}$ miksery ... nie ... tera sie rzuci do miksera ... i ozdrobnito (!) ... i ten ... wode sie odlato ... mon ke matka tam brała z tej ... i jajko czy coś tam ... i to zamieszała ... i ... i sól ... i ten ... do smaku ... nie ... i na patelnie ... i piekło sie ... tam nabierała ... i tyżkom wazowóm wtożyła ... bo my duże mieli te plince ... nie ... ale tak ... żeby carny nie byt ... nie ... to pilnowała ... carny to zaraz odtożyła dla kotków ... $i$... bo to już jez gorzki smak ...

(Dąbrówka Wlkp. Świebodzin county; informant born in 1933; recorded in 2009).

These two fragments come from longer conversations held with inhabitants of the same village. Each fragment was registered during a conversation which was over an hour long which is conducive to the respondent's natural utterance, his/her familiarity with the situation.

Therefore, to what extent old field material can be reliable for a synthesis? The above analyses clearly indicated that these texts, while registered as speech, do not always fulfil the expectations of contemporary research. Full characteristics of the syntactic complexity may be developed with respect to the respondents' registered longer, natural utterances. The presented findings are also evidence that activities aimed at compiling lexicons of specific dialects need to be preceded by targeted field explorations (theme conversations). The utterances of the village inhabitants, obtained haphazardly, very often fail to confirm the field persistence of too many linguistic units characteristic of a specific dialects. Beside phonetic phenomena, this also indicates the remaining levels of organisation of a dialectal utterance*.

* This is a modified and extended version of the text Cechy definicyjne gwar w języku mieszkańców wsi, [in:] Z polskich studiów slawistycznych, seria XII. Językoznawstwo. Prace na XV Międzynarodowy Kongres Slawistów w Mińsku 2013, Warszawa 2012, pp. 159-166. 


\section{Bibliography}

AJKLW (1979-2005), Atlas języka i kultury ludowej Wielkopolski, vol. I-VI, Z. Sobierajski, J. Burszta (eds.), vol. VII-XI, Z. Sobierajski (ed.), Wrocław-Warszawa-Kraków-GdańskŁódź-Poznań.

Gruchmanowa M. (1970), Gwary zachodniej Wielkopolski, Poznań.

Nitsch K. (1929), Wybór polskich tekstów gwarowych, Kraków.

Nowak H. (1982), Gwary poludniowej Wielkopolski, Poznań.

Otrębski J. (1953), Co utrwalać na plytach?, "Lingua Posnaniensis”, IV. Extra issue. Biuletyn Fonograficzny 1, Poznań, pp. 55-70.

Skubalanka T. (1977), Nie realizowane formy fleksyjne, "Annales Universitatis Mariae Curie-Skłodowska", section F, Lublin, pp. 263-270.

Sierociuk J. (2003), Założenia metodologiczne badań języka wsi, [in:] Poznańskie Spotkania Językoznawcze, vol. XI, Z. Zagórski, Z. Krążyńska (eds.), Poznań, pp. 131-136.

Sierociuk J. (2009), Zasoby fonograficzne Zakładu Dialektologii Polskiej UAM i ich przydatność $w$ badaniach procesów rozwojowych polszczyzny mówionej, [in:] Polszczyzna mówiona ogólna i regionalna. Materials from a national scientific conference held in Krakow on 25-26 September 2008, B. Dunaj, M. Rak (eds.), Kraków, pp. 179-188.

Sobierajski Z. (1985), Teksty gwarowe z zachodniej Wielkopolski, Wrocław-Warszawa-KrakówGdańsk-Łódź.

Sobierajski Z. (1995), Teksty gwarowe ze środkowej Wielkopolski, Poznań. 